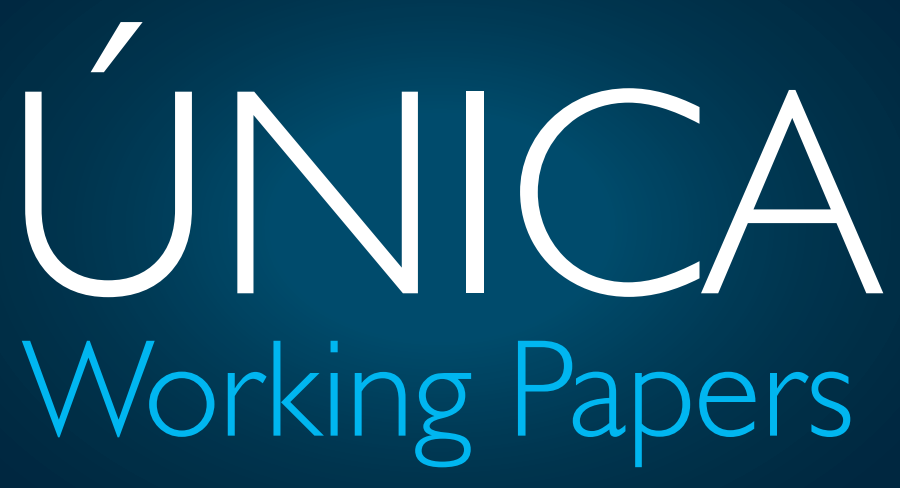

DECONSTRUCTING AND CRITIQUING INTERCULTURALITY THROUGH FILM WITHIN A BILINGUAL EDUCATION PROGRAM IN BOGOTÁ, COLOMBIA

- CRISTINE KHAN AND CARLO GRANADOS-BELTRÁN -

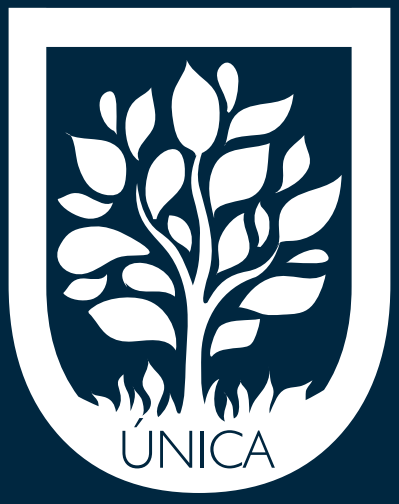

www.unica.edu.co 


\section{DECONSTRUCTING AND CRITIQUING}

INTERCULTURALITY THROUGH FILM WITHIN A BILINGUAL EDUCATION PROGRAM IN BOGOTÁ, COLOMBIA

Cristine Khan and Carlo Granados-Beltrán

Institución Universitaria Colombo Americana-ÚNICA, Bogotá, Colombia 
Facultad de Educación

Programa de Licenciatura en Bilingüismo con Énfasis en Español e Inglés

Bogotá D.C.

2018

Reg. SNIES: 106242

Vigilada MinEducación

Working Paper - Resultado de Investigación

Grupo de Investigación Innovation on Bilingual Education - INNOBED Categoría B

Colciencias

Dirección de Investigaciones

Calle 19 No. $2^{\text {a }}-49$, Piso 3

Centro Colombo Americano

Teléfono: 2811777 Ext. 1291

dir.investigaciones@unica.edu.co

$\underline{\text { www.unica.edu.co }}$

DOI: https://doi.org/10.26817/paper.02

Prohibida la reproducción parcial o total de esta obra sin autorización de la Institución Universitaria Colombo Americana - ÚNICA 


\section{Deconstructing and Critiquing Interculturality through Film within a Bilingual Education Program in Bogotá, Colombia}

Cristine Khan and Carlo Granados-Beltrán

BA in Bilingual Education, Institución Universitaria Colombo Americana-ÚNICA, Bogotá, Colombia

Cristine Khan

khan.cristine@gmail.com

Av. 19 No. 2 - 49

Bogotá, Colombia

$+5712811777$

Cristine Khan has an MSc in Migration Studies and Social Cohesion from the University of Amsterdam and the University College of Dublin through a joint degree Erasmus Mundus program and a BA in Sociology from Wesleyan University. Originally from New York City, she arrived to Bogotá in 2013 as a Fulbright scholar, working as an English Language Assistant and returned in 2016 to work as a full-time professor and researcher within the Bilingual Education major at ÚNICA. Her areas of research are cultural identity, postcoloniality, migrations, ethnicity, and intercultural relations, influenced by her hometown and experience abroad.

Carlo Granados-Beltrán

carlogranados@gmail.com

Av. 19 No. 2 - 49

Bogotá, Colombia

$+5712811777$

Carlo Granados Beltrán holds an MA in British Cultural Studies and ELT from the University of Warwick in England and an MA in Applied Linguistics to the Teaching of English as a Foreign Language from Universidad Distrital. Francisco José de Caldas in Bogotá, Colombia Currently, he is doing a $\mathrm{PhD}$ in Education at Universidad Santo Tomás in the same city. He is a teacher researcher at the BA in Bilingual Education at Institución Universitaria Colombo Americana - ÚNICA. His areas of research are decoloniality, interculturality, initial teacher education, and language pedagogy. 


\section{Table of Content}

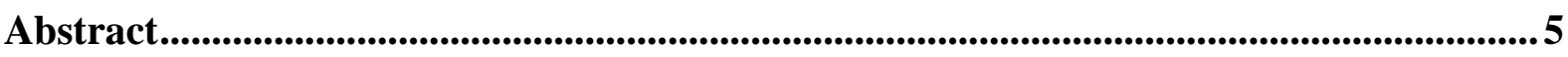

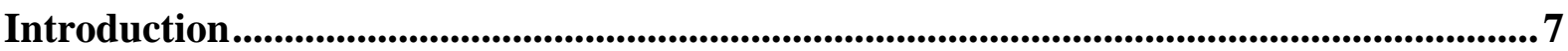

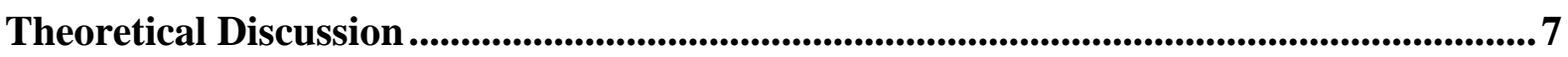

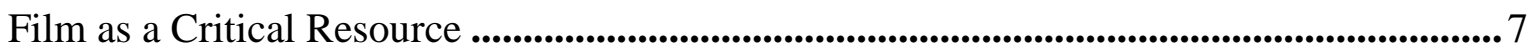

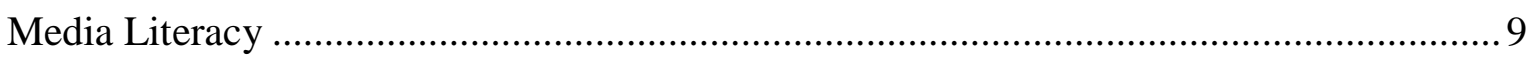

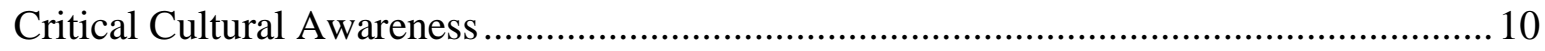

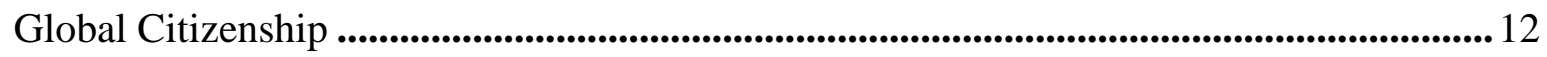

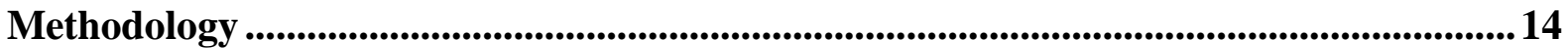

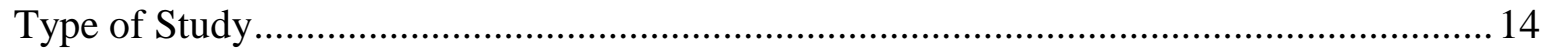

Setting............................................................................................................................................................. 15

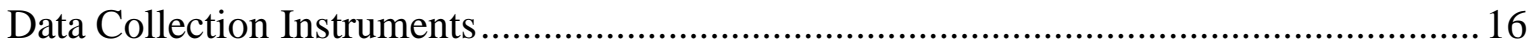

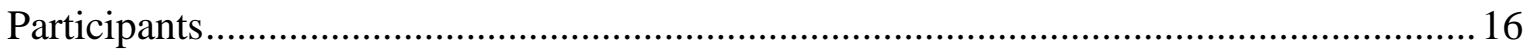

Film Choices and Workshop Design ................................................................................... 17

Findings............................................................................................................................................................... 18

Understanding diverse cultural contexts through film .................................................. 18

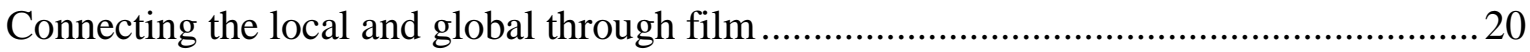

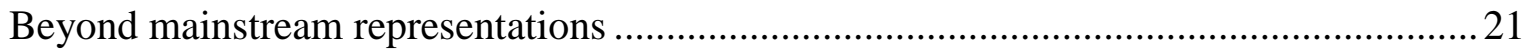

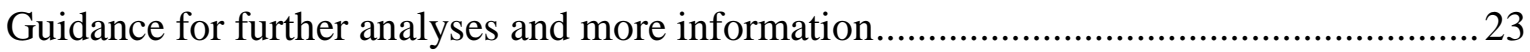

Conclusions .................................................................................................................................................... 25

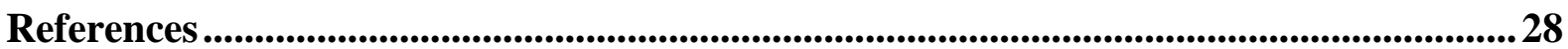

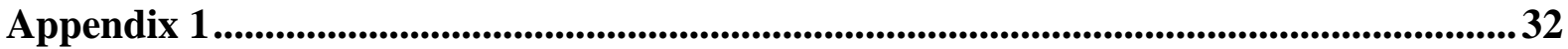

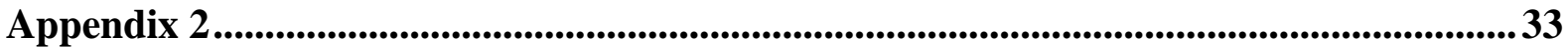




\title{
Deconstructing and Critiquing Interculturality through Film within a Bilingual Education Program in Bogotá, Colombia
}

\begin{abstract}
Popular culture stimulates the consumption of certain perspectives about global contexts. In many English as a Foreign Language (EFL) classes, educators incorporate music, movies, or TV shows to provide students with material from Anglophone cultures that also emphasize certain cultural aspects; however, many times there is a lack of critical media literacy in using such materials, which reinforces stereotypes and essentializes ideas about certain cultures. This study took place within a BA program in Bilingual Education in Bogotá, Colombia, and analyzed how two content-based English courses, focused on interculturality, help in deconstructing the role of film in shaping students' perspectives about both global and local contexts. Using the methods of critical media literacy, students were given workshops after watching various films in class, developed in-class discussions, and participated in focus groups, guiding them to critically analyze different positionalities of both characters and contexts within the films. Through the data analysis, it is evident that, when given the proper mediation, films can be a powerful resource in aiding to promote citizenship, decolonize intercultural topics, and construct counter-narratives.
\end{abstract}

Keywords: critical media literacy; critical cultural awareness; citizenship

\section{Resumen}

La cultura popular estimula el consumo de ciertas perspectivas de los contextos globales. En las clases de Inglés como Lengua Extranjera, los educadores incorporan música, películas, o programas de televisión que brindan a los estudiantes material auténtico que enfatiza algunos aspectos culturales; sin embargo, muchas veces hace falta la aplicación de una literacidad crítica de medios al utilizar dichos materiales, ya que terminan por reforzar estereotipos y esencializar ideas acerca de determinadas culturas. Este estudio se realizó en un programa de Licenciatura en Educación Bilingüe en Bogotá, Colombia y analizó cómo dos clases de contenido en inglés, enfocadas en la interculturalidad, contribuyeron a deconstruir el papel del cine en la formación de perspectivas de contextos locales y globales. La literacidad crítica de medios orientó el diseño de los talleres, las discusiones grupales y los grupos focales que permitieron analizar críticamente las diferentes posiciones subjetivas de 
los personajes y de los contextos de las películas. El análisis de datos destacó que cuando existe una mediación adecuada, las películas son un recurso poderoso en el fomento de la ciudadanía, la decolonización de la interculturalidad, la construcción de contra-narrativas, y la educación de profesores capaces de empatizar y suspender prejuicios.

Palabras clave: literacidad crítica de medios, consciencia crítica intercultural, ciudadanía. 


\section{INTRODUCTION}

Upon watching the movie My Name is Khan (Johar, 2010) in a class on Intercultural Communication in Bogotá, Colombia, a student, on the verge of tears, expressed her concern about the experiences of Muslims in the United States. She had heard about the supposed radical nature of this religion associated with terrorism, but was never exposed to any information recounting the perspective of the 'other.' Popular culture, especially from the United States, has become part of everyday lives, dictating global perceptions, and reproducing stereotypes about the exotic 'other,' as seen through the eyes of an American majority. Globally, students within English as a Foreign Language (EFL) classes are exposed to skewed images of American and other cultures through movies, music, and news. This gradual diffusion of information in many ways disenfranchises minority groups and privileges certain cultures over others (Philippson, 2008; Grosfoguel, 2011).

This research argues that film is an important tool that provides students in contentbased EFL courses with media literacy, which helps them develop critical cultural awareness of both global and local contexts within their own countries. When given the proper mediation, film can help in constructing counter-narratives that move beyond hegemonic standards of Western culture, which pushes students to become critical global citizens. Based on our qualitative research through in-class workshops and focus groups, we highlight three specific ways in which film is a necessary resource when teaching about intercultural topics: an agent in promoting global citizenship; a way to decolonize forms of learning about Anglophone cultures; and a catalyst in constructing counter-narratives of subaltern students.

\section{THEORETICAL DISCUSSION}

\section{Film as a critical resource}

Hooks (1997) affirms that pedagogy and learning are in popular culture. Therefore, she encourages the use of films so that students with diverse social and ethnic backgrounds 
can better grasp theories of difference and alterity that present similar stories to theirs; also, the topics become more interesting and engaging for students. Films help in scaffolding complex sociological theories and may be useful in deconstructing the intersections among different identity markers such as social class, gender, race and ethnicity.

Film is also a form of representation, shaping how people conceptualize and give meaning to different cultures (Hall, 1997). By consuming certain artefacts that depict culture, we give meaning to culture. At the same time, popular culture, such as the media, plays a key role in altering how one perceives the 'other', and how differences are created and maintained (Giroux, 2001; Arikan, 2002; Kellner \& Share, 2005). With this in mind, film can be a useful source to critique the same differences that they seemingly create and sustain. In using film or other forms of media, it is important that students are critically engaged and understand misrepresentations and under-representations presented in the film; they must be able to use them to identify cases of inequality and injustice (Kellner \& Share, 2005).

Film can be used as a pedagogical tool and as a way to promote critical thinking skills in students (Giroux, 2001; Arikan, 2002; Briam, 2010). Giroux (2001) argues that through movies, students can become "critical cultural agents" (p. 586). He contends that the role of film is twofold: it can provide both entertainment and relief, while also constructing and challenging critical knowledge. Movies have the power to incorporate a certain ideology, using power to construct meaning and pleasure for the viewer, while also illustrating contradictions in societal contexts. Giroux (2001) asserts that mainstream films, especially from the U.S., often allow viewers to consume specific constructions of certain identities. Still, it is important for educators to incorporate theoretical resources when using these tools in the classroom. To promote critical dialogue that intersects popular culture and pedagogy, an educator must provide the, "theoretical resources necessary to engage critically how dominant practices of representation work to secure individual desires, organize specific forms of identifications, and regulate particular modes of understanding, knowledge, and agency" (Giroux, 2001, p. 595). Therefore, films must be critiqued using different theoretical frameworks and dialogue facilitated by the teacher.

Higbee and Lim (2010) share similar ideas, but focus on how non-Western cinema can present transnational and postcolonial perspectives. They argue that one must incorporate transnational cinema focusing on cultural identity related to diaspora and postcolonialism, 
and challenging the Western construct and perspective of nation and culture. Such films tend to reflect power dynamics more consciously. At the same time, one must have the tools to critique Western portrayals of postcoloniality, politics and power, and question the hegemony of English in many transnational films. In this way, a critical discursive approach is necessary to evoke these changes in how film is used (Higbee \& Lim, 2010).

\section{Media literacy}

Critical media literacy provides a tool in analyzing films. García, Seglem, and Share (2013) define critical media literacy as expanding the traditional notion of literacy to include different forms of mass media communication, popular culture and technology; this encourages a critical analysis of the relationship between media and audiences, information and power. It also pushes students to explore ideologies and connections between power and information which are not easily visible. This allows for the study of multiple narratives and ideological power structures. Moreover, in an era of standardization, high-stakes testing, and scripted curriculum, educators must recognize how conservative education and commercial media challenge their role as replicators of dominant ideologies and oppressive social structures (Garcia, Seglem \& Share, 2013).

Burn and Durran (2007) contend that media forms, such as films, function similarly to print text, which are both created by markings and involve a selection and combination of signs, which require specific skills to construct and decode meaning. Accordingly, media literacy refers to the body of knowledge to decode signs, analyze texts, and understand representations. In this way literacy is viewed as cultural, critical, transformative and creative. It is cultural because it represents important ideas and values for societies. It can be critical by counteracting ethnocentric positions and idealizations of cultures and countries; the diversity of films can expose students to other kinds of plots and stories different from commercial Hollywood movies. Additionally, media literacy is transformative and creative because it involves not only understanding, but reconstructing the text through speaking, writing, or other media.

In order to analyze a cultural text or artefact through media, Du Gay, Hall, Jones, Mckay and Negus (1997) propose five elements: representation, identity, production, consumption and regulation. This project focuses principally on issues of representation and 
identity. Representation addresses the meanings attached to the artefact as well as the meanings the consumers grant to it, and identity underlines the agents, individuals, groups or entities, who produce, consume and regulate the artefact. In this research, media literacy allowed participants to recognize representations of different identity markers such as gender, race, sexual orientation, as well as their own representations as individuals.

\section{Critical cultural awareness}

Analyzing the cultural components of film is vital in critically understanding these artefacts (Hooks, 1997). Byram (1997, p. 53) considers critical cultural awareness as a key component to his model of intercultural communicative competence, defined as "an ability to evaluate critically, and on the basis of explicit criteria, perspectives, practices and products in one's own and other cultures and countries". This dimension is based upon the French (engagement) and mostly German (Politische Bildung) traditions of political education, in which language is linked to education for democracy and citizenship (Byram, 2012).

Critical cultural awareness involves identifying and analyzing documents in one's own and other cultures and interacting and mediating within intercultural exchanges that incorporate knowledge, skills and attitudes based on the notion of political education. The expected outcomes for this dimension are, among others:

respect for the value, the dignity and freedom of every individual person (...), recognition of the importance of peace, absence of violence and the participatory and constructive resolution of social conflicts and problems (...), recognition of pluralism in life and in society, respect for foreign cultures and the contribution to human development (...) trust and solidarity and the struggle against racism, prejudices and discrimination (...) (Himmelmann, 2003, as cited in Byram (2008, p. 160).

Although Dervin (2010) acknowledges the potential of critical cultural awareness or political education, he also critiques Byram's model for promoting essentialized ideas of the concept of culture within a rationalist European framework. Other authors question the utopian nature of the model and its excessive reliance on participants' honesty and willingness to become intercultural (Parekh, 2003; Dervin, 2010; Vodopivek, 2012).

In relation to essentialization, Dervin (2016, p. 81) suggests "a liquid realistic approach" in which, although non-essentialism and non-culturalism are acknowledged as noble objectives to be considered in intercultural education, it is understood that these are 
difficult to reach; therefore, essentialism is seen as a 'universal sin', and the inevitability of using conventional standard codes, and clichés to classify people is accepted. Therefore, the intercultural is analyzed in its 'simplexity', that is, in its dialectical nature of simultaneously simple and complex. Most importantly, it is necessary to comprehend that as "researchers we can only reach a practical simplification of intercultural phenomena" (Dervin, 2016, p. 81).

Holliday (2011) states that when approaching cultural topics, we run the risk of essentializing individual behaviors by focusing on the stereotypes about specific cultures. In language teaching, culture unfolds in universal, national and local levels that reflect historical relations of power and ways of speaking (Kramsch, 1995, p. 89). Therefore, it is important to be conscious of reinforcing the dichotomies of us-them and insider-outsider. Still, the learning of "culture" often excludes the experiences of minority racial and ethnic groups, as the "other" (Kubota \& Lin, 2006). In the same line, to approach essentialization, Dervin (2016) proposes (1) creating encounters in which students can examine their resistance to failure and become critical of what they learn and (2) raising students' awareness about the fragilities in interculturality, in which essentialized discourses and identities can violate the others' human rights, and (3) intersecting the cultural with other identity markers, such as race, gender and social class. Thus, there is a need for critical consciousness when learning about culture, which can create "critical cross-cultural literacy" (Kramsch, 1995 p. 89).

Critical cultural awareness for this study entails, then, a critique of both foreign and one's own societies and cultures because foreign language learning leads students' attention to the countries where the languages are spoken and to the communities and societies in those countries; hence, teachers must serve as mediators between the two cultures and encourage students to think critically, moving beyond basic cultural notions of "otherness" and breaking down stereotypes.

Even though critical cultural awareness is the core dimension to Byram's model of intercultural communicative competence (2012), it has not been widely explored in the intercultural learning framework (Nugent \& Catalano, 2015). Some explorations have been made about critical cultural awareness and stereotyping (Houghton, 2013) and othering as a way to raise critical cultural awareness (Moncada, 2016); however, studies exploring the connections among critical cultural awareness, global citizenship and critical media literacy are scarce. 


\section{Global Citizenship}

The skills Byram (1997) proposes for the dimension of critical cultural awareness coincide with the ones proposed by OXFAM UK (1997) and UNESCO (2015). Global citizenship group skills related to an awareness of the world in its economic, social, and political dimensions and the influence they have at both local and global levels in our role as world citizens. Global citizenship education is divided in three dimensions: first, the cognitive dimension related to acquiring knowledge, understanding, and critical thinking about global and local issues and the interdependence of countries and populations; the second dimension is linked to common humanity with an emphasis on common values, empathy, solidarity and respect for diversities; lastly, the behavioral dimension means acting responsibly at global and local levels for a peaceful and sustainable world (UNESCO, 2015).

Global citizenship includes environmental literacy, digital literacy, media literacy, conflict resolution, critical thinking and inquiry, outrage for social injustice, recognition and appreciation of multiple identities, and concern and willingness to act against inequalities caused by gender, social class, religion or age. Müller-Hartmann and Schocker-von-Ditfurth (2007) propose developing these skills in class with tasks which involve looking at action in literary texts - for the case of this research, in films - from the perspective of characters, so that students are able to experience situations from different cultural viewpoints. Moncada (2016, p. 138), in her article about analyzing othering as a way to raise critical cultural awareness, also argues that cultural products can be used to promote self-reflection and awareness-raising so that students can deconstruct common-sensical assumptions and marginalizing discourses of colonialism, ethnicity, language, and sexual orientation which contribute to the maintenance of power imbalances and inequality.

Additionally, the 2016 Colombian Ministry of Education proposed the Basic Standards for Citizenship Competences (Estándares Básicos para Competencias Ciudadanas) which make part of the cross-curricular competences that all teachers, including language teachers should develop in primary and high school, and now even more due to the transition the country is making to a post-conflict situation. The descriptors included in this official document also coincide with the skills that make part of critical cultural awareness and global citizenship. Also, school communities are questioned to reflect on what language classes can 
contribute to communicative competences to prevent conflict and discrimination. It also explores how to incorporate a critical reading of mass media to promote citizenship, which involves the development of critical media literacy skills.

Kellner and Share (2005, p. 370) claim it would be irresponsible to neglect how media socialize and educate people, even more, when "individuals are not aware that they are being educated and constructed by media culture, as its pedagogy is frequently invisible and unconscious"; therefore, this project aimed to provide students with the tools to look beyond what they see on the screen. In this respect, critical media literacy must form part of transformative education by promoting critical analysis and creating spaces where students attempt to struggle against oppression and create their own representations. In doing so, they must be able to understand how the different subject positions, such as ethnicity, race or gender, may affect one's viewpoint (Kellner \& Share, 2005). These varying contextualizations permit students to critically analyze themselves and others within a global context, thus fostering critical global citizenship.

By understanding film as a document that can be 'read' and interpreted with the strategies provided by media literacy, students in this research learned to watch with tools from the classes and workshops that encouraged critical deconstructions of implicit and explicit values. They also learned to search for alternative images of themselves and "others" in non-Anglo media. This can aid students in reconstructing their own identities and thinking about themselves in a larger global context (Pegrum, 2008, p. 149).

At the same time, it is important that former colonized countries unlearn by critiquing the domination of the first world, and dismissing the representation of the West as the source of universal knowledge of culture (Andreotti, 2006; Spivak, 1988). In these cases, critical literacy is necessary to obtain critical global citizenship; learners must be able to critique and analyze different perspectives of language, power, social practices and social groups (Andreotti, 2006). Using critical media literacy strategies to analyze film allows students to both learn from and resist media representations (Kellner \& Share, 2005). In doing so, students may comprehend conflictive societal aspects, and use technology as a source of social communication. This in turn can help students develop skills that enhance democratic participation and help them become better citizens. 


\section{METHODOLOGY}

\section{Type of study}

This study was framed using a qualitative paradigm and followed a case study methodology. Hancock and Algozzine (2006, pp. 10 - 11) describe case studies as "intensive analyses and descriptions of a single unit or system bounded by space and time." Case studies can also be used to describe an intervention and the real-life context where it took place (Yin, 2003). Gall, Gall and Borg (2003) explain that case studies usually involve fieldwork to interact with participants in natural settings, offering both and emic and etic views of the phenomenon. For the purposes of this study, the emic perspective was provided by the discussions held in class, while the etic view was obtained through the in-class workshops adapted by the researchers.

When using case studies, data are collected over extensive periods with various techniques; it is common that the researcher spends more time in the context being studied in comparison to other kinds of methodologies (Gall, Gall \& Borg, 2003; Hancock \& Algozzine, 2006). Following the exploratory nature of case studies, this research attempted to understand the role of film in developing intercultural awareness, which could aid in constructing citizenship in its global dimension. The research was conducted by two teachers of two different courses related to intercultural topics throughout one academic semester.

Data analysis in case study research is characterized by being narrative in nature. These narrations are composed of key aspects which are enriched by direct quotes from the participants, extracts from interviews, and, in some cases, anecdotes or literary techniques which create a more vivid image of the phenomenon studied (Hancock \& Algozzine, 2006). Neiman and Quaranta (in Vasilachis, 2006) also state that the analysis of information in case study research is composed of direct interpretation or of construction of categories created by processes of aggregation, as well as establishing correspondences or defining patterns. For the data analysis, the researchers opted for establishing categories based on the commonalities found among the different instruments. 


\section{Setting}

This classroom research took place at a BA program in Bilingual Education at a private university located in Bogotá, Colombia. The institution offers two academic programs: first, the BA in Bilingual Education; and second, the Specialization in Bilingual Education, addressed to in-service teachers. The university incorporates a Liberal Arts philosophy by fostering critical thinking, and an open-minded perspective towards diverse populations. The curriculum of the BA program reflects this by offering several subjects about the relation among language, culture, identity, and history; among them, we can find Language, Culture and Identity, Intercultural Communication, Identidad Latinoamericana (Latin American Identity), and Colombia Indígena (Indigenous Colombia). Some of these subjects are taught in English in order to strengthen students' competences in both content and language skills.

This study was developed with students taking the classes of Language, Culture and Identity (LCI) and Intercultural Communication (IC), which are taught in English. LCI is given to students in their first semester, while IC in the third semester. Both of these courses complement each other; LCI focuses on introducing the connections between identity and language, whereas Intercultural Communication provides both theory and practice about different cultural dimensions that influence communication in diverse groups (See Table 1). For example, LCI provides weekly themes on topics such as race, class, gender and sexuality. In a similar fashion, Intercultural Communication strengthens specific aspects that directly influence the mixing and interactions of different cultures such as immigration, multiculturalism, religion, conflict, and identities.

\begin{tabular}{|l|l|}
\hline $\begin{array}{l}\text { Overview of Topics in Language, } \\
\text { Culture, and Identity }\end{array}$ & $\begin{array}{l}\text { Overview of Topics in Intercultural } \\
\text { Communication }\end{array}$ \\
\hline Approaches to the study of culture & Colonialism and Communication \\
\hline Linguistic Nationalism & History of Immigration \\
\hline Ideology & Multiculturalism and Diversity \\
\hline Hegemony & Religion \\
\hline
\end{tabular}




\begin{tabular}{|l|l|}
\hline Class/Classism & Cultural Dimensions \\
\hline Race/Racism & Histories \\
\hline Gender & Conflict \\
\hline Masculinity & Representations \\
\hline Sexuality & Whiteness and Identities \\
\hline Subcultures & Social Justice and Peace Education \\
\hline
\end{tabular}

Table 1. Overview of course topics

\section{Data collection instruments}

Yin (2003, pp. 13 - 14) highlights that case study research incorporates "multiple sources of evidence, with data needing to converge in a triangulating fashion"; therefore, for this study, the researchers used different sources of data. First, as part of class assignments, students saw three films in each class, and completed a standard in-class workshop form for each film (See Appendix 1). These workshops incorporated questions related to media literacy, such as the link between the stories in the film and the Colombian context, the authenticity of the historical events depicted in the movies, and the ways in which the films represented different social groups, among others. Additionally, after the film screenings in class, students participated in discussions. Finally, at the end of the implementation, students from each course participated in separate focus groups designed to understand their perceptions about the pedagogical usefulness of films and how effective they were in fostering citizenship (See Appendix 2).

\section{Participants}

28 students from the BA program in Bilingual Education participated in this project; there were 10 male and 18 female participants ranging from 17 to 25 years old. Students were taking either the course Language, Culture, and Identity (LCI) or Intercultural Communication (IC). Both of these courses are content-based and taught in English. In Language, Culture, and Identity, the students were between A2 and B2 levels of English 
proficiency, whereas in Intercultural Communication, students had a B1 or B2 proficiency according to the Common European Framework of Reference for Languages (2001).

\section{Film Choices and Workshop Design}

The films chosen were used to complement specific and pertinent class themes throughout the courses. As students are learning English, and given the presence of American culture in Colombia, they tend to consume Hollywood movies and culture (Arda, 2012). Therefore, it was important to choose non-mainstream movies that highlighted the stories of diverse groups of people; but also students were given tools through the workshops and class discussions to be critical of the messages portrayed in more commercial Hollywood films, such as V for Vendetta or Crash. In LCI, students were also given the chance to watch other movies selected by the teacher and assigned as homework in relation to class themes; after doing this, they had group discussions about these movies during class. The films seen in whole-class screenings are listed in Table 1 below:

\begin{tabular}{|l|l|l|}
\hline Film & Course & Themes related to courses \\
\hline My Name is Khan (2010) & IC & Migration, Religion, Multiculturalism \\
\hline Incendies (2010) & IC & Conflict, Religion, Histories \\
\hline Crash (2004) & IC & Identities, Stereotypes, Multiculturalism \\
\hline V for Vendetta (2005) & LCI & Ideology, Politics, Media manipulation \\
\hline Far from heaven (2002) & LCI & Gender roles, Sexual orientation, Racism \\
\hline
\end{tabular}

Table 1. Movies seen as whole-class activity.

The workshops were designed based on an open-ended questionnaire that incorporated general questions about the film, and questions relating the films to Colombian society. Some questions were inspired by media literacy projects, such as Canada's Centre for Digital and Media Literacy (2005) and NAMLE's Core Principles of Media Literacy Education in the United States (2007) (See Appendix 1). Students filled out these activities based on their personal reflections of the movies. The in-class workshops complemented these questions and analyzed specific themes that were addressed in the movies through 
discussions activities; these were not standardized, but included small group discussions, mind-maps, poster graphics, and analyzing movie reviews.

\section{FINDINGS}

In the in-class movie workshops, class discussions, and focus groups, students were able to elaborate on the various social dynamics and realities from the movies. They also drew connections between themes discussed in class and the experiences of characters in the movies. In the focus groups, about 10 students participated for each course, and were asked general questions about their perspective in using the films to complement the theories learned in class about each weekly topic (See table 1). In understanding the common threads between the various in-class and written workshops and focus groups, it should be noted that movies can play four distinct roles within such classes on intercultural themes:

\section{Understanding Diverse Cultural Contexts through Film}

Most students believed that the movies encouraged them to learn about and understand various diverse cultural contexts. As Arikan (2002) explains, when films are nontraditional, going beyond the typical Hollywood action or romance movies, they often open spaces to reflect on perspectives that are different from those of majority groups. At the same time, such films work in dispelling preconceived notions of culture, allowing for the representation of multifaceted identities (Dervin, 2010). As one student expressed during the focus group, the movies were able to unmask issues relating to groups of people that they had not recognized, "The movies show us realities that we are not close to and give us a better understanding of how other people live (...) It makes us get close to a reality that is different." (Focus group, June 5, 2017). In this example, film presents a perspective of the 'other.' It allows students to contextualize realities that are not necessarily central to mainstream Hollywood movies.

Another student highlighted how one particular movie, My Name is Khan (Johar, 2010), helped them construct a different point of view about Muslims and immigration in the United States; at the same time, it provided a clear image of how a minority group could experience rejection. The student felt that having this understanding could allow for better relations with diverse groups and generate more empathy for situations of marginalization: 
In the case of My Name is Khan, I think we could feel what they feel when the son died. In my case, I never thought that there was such racism and rejection and that it could be that bad. I saw the movies and realized how sad those things were (...) if you know the problem of people you can get close to them. The movie helped me understand. (In-class workshop, February 6, 2017)

As evidenced, when provided with proper stimulation and guidance, film can be an important tool in implementing critical literacy into the classroom. It fosters the skills to deconstruct oppressive structures and ideologies (García et al., 2013). Additionally, after watching the movies, students expressed an interest in further understanding Islam and the reasons why it has become such a stigmatized religion. Because of this, a mini-lesson was provided on the various factors that influence Islam, and the history of Muslims in the United States.

In mentioning the same film, another student drew connections to preconceived ideas about discriminatory policies in the United States (In-class Workshop, February 6, 2017). When asked about what new aspects they learned from the film, the student was awestruck in realizing conditions of poverty in the United States, and stated,

The movie was a bit shocking. It showed us how people and why people are the way they are and the reality that the government does not help poor people or how poor people live in terrible conditions. It also showed how discrimination affects so many people. (In-class Workshop, February 6, 2017)

Using film as an intercultural tool helped him debunk mainstream representations about the United States and how people live. In this way, the consumption of movies can reiterate mainstream representations, but in applying critical analysis, it may also aid in demystifying the construction of certain images about specific cultures. Additionally, they were able to identify the role of positionality in constructing one's experience in society (Kellner, 2005). This is an integral part of not only promoting critical intercultural awareness, but also fostering critical global citizenship.

Furthermore, students identified the multiplicity of societal concepts, by noting and critiquing the use of stereotypes both in film and their prior conceptions of specific cultures. Throughout the workshop students made clear connections between the media representations and perceptions of certain groups. One of the conversations led to a discussion of the role of stereotypes in promoting intolerance; students complemented this activity by noting various 
stereotypes about Colombia and reasons why they were not generalizable (Field notes, February 6, 2017).

\section{Connecting the local and global through film}

Film in education within more marginalized populations may aid in allowing students to understand different realities, and to better relate to contexts within their own societies, seeing themselves and their stories represented in specific movies. Some students at the BA program come from difficult backgrounds, and reside in some of the most impoverished neighborhoods in Bogotá. As the city is socially stratified, discrimination, especially classism, pervades social settings. This often leads to certain stigmatizations and stereotypes of people from certain places throughout the city. The movies chosen for both classes highlight the stories and experiences of different social groups that are not often represented in more mainstream movies. This, in turn, provided an opportunity to unfold connections that may exist between marginalized characters in the movies, and students' experiences. One student recognized the effects of using stereotypes in daily interactions:

I think I have changed the fact that I unconsciously used to make many stereotypes about people. Now before I speak I try not to make stereotypes, I want to see other sides of people and not just the stereotypes. (Focus group, June 5, 2017)

Viewing the treatment of minority groups within the movies motivated some students to reflect on the dangers of stereotyping and the subsequent effects they may have on other people, especially from other cities within Colombia:

In my case, I had many stereotypes about rolos [people from Bogotá], and I think I've tried to become a better citizen and I'm trying to think about them in a different way and try to be a good citizen here (...) when I hear people in Bogotá say things about costeños [people from the coastal regions] or paisas [people from Antioquia], I always get angry, because I never have had those stereotypes. I had stereotypes about rolos. I saw that if I feel angry about those stereotypes, then maybe I should stop making stereotypes about them. (Focus group, June 5, 2017)

As Kellner and Share (2005) contends, it is vital that educators provide facilitation and tools that foster engagement in critical thinking when watching movies. This encouraged students to recognize and analyze forms of discrimination that can also help them in becoming more critically aware in their everyday lives. Additionally, the perception of the 'other', often upheld in films, tends to privilege certain cultures and identities over others (Giroux, 2001). However, students were given the means to deconstruct such representations, 
and draw connections to their own lives. As students from lower-income backgrounds, from a country considered to be part of the Global South or 'developing world', they are inherently part of a global hierarchy, which marks them part of a lower status or subaltern group (Grosfoguel, 2011). Still, students are constantly exposed to mainstream American popular culture, allowing them to form certain ideas of social groups from the United States. Interestingly, the workshops provided a space for them to relate what they viewed in the movies to their own lives, which challenged their previous perspectives and pushed them to make new connections. One student noted a connection between Muslims and Latinos from watching the movie, My Name is Khan:

(...) I saw a connection between Muslims and Latinos. Maybe the discrimination. For example, people stereotype them as being terrorists and they stereotype us as being narcos. (In-class Workshop, February 7, 2017)

In this case, students were able to recognize the negative effects of stereotypes from varying contexts and relate them to their own social environments; they drew connections about how mainstream stereotypes about certain social groups shape social perceptions of those groups. Additionally, the movie Crash (Haggis, 2004) sparked interest and debates about social class and racism in relation to Colombia. Students found the issue of social class to be very common in Colombia, and used the movie to pinpoint the flaws of classism and the stratification of Bogota:

Many people stereotype about people from low social classes and I have learned that that is not true. The same with people from higher classes; we stereotype that they are arrogant or spoiled, but that is not true for everyone. I think we have learned to start thinking about people as people. (In-class Workshop, May 15, 2017)

It must be noted that the movies as a whole may not have entirely shaped such perspectives, but rather gave students more of an incentive to critically reflect on their everyday spheres.

\section{Beyond Mainstream Representations}

Furthermore, students noted that the tools of the in-class workshop helped them challenge mainstream depictions of certain groups. Media representations are a reflection of social dynamics within society. As Hall (1980) contends, in understanding how certain ideas prevail through media, a message is encoded through certain images and words, and then decoded by individuals who are influenced by their ideologies and positionality within society. Therefore, different images present varying messages based on the individuals and 
their social contexts. Still, as certain groups tend to be consistently depicted in certain ways, stereotypes are formed. Hooks (1997) argues that mainstream representations in the media uphold racist and patriarchal perspectives; it is important that educators attempt to deconstruct such images in their classes. Within the in-class workshops, students illustrated that the movies helped in going 'beyond the everyday contexts.' They were able to see different perspectives, and the various questions in the workshops facilitated critical thinking that allowed them to see beyond what was presented. For example, when asked about the critical skills taken away from watching and analyzing the films, one student mentioned gaining new insights about a movie she watched before taking the class:

I had watched Bend it Like Beckham before, but I saw it more for the romance and the comedy, but the last time I was watching it with more serious and deeper topics. I had to open my mind to see the whole perspective. (Focus group, June 5, 2017)

The tools given throughout the workshop facilitated deeper analysis about the films. Being able to discuss the questions presented in the in-class workshops and reflect individually gave students a more critical take on the films, and allowed them to directly address any questions or doubts that they had. In this case, previous class materials also helped in better understanding topics in the movies such as interculturality and multiculturalism.

In reflecting on the movie Incendies (Villeneuve, 2010), one student mentioned that having a visual representation of conflict in the Middle East, helped her in broadening her perspective,

In our classes we knew aspects of this type of conflicts in the Middle East, but to watch these situations personified in a film (although it was a fictitious story) shows more clearly the state of affairs in those countries in war, what is the reality of foreigners, both those who have had to leave their land, and also those who don't have a place that belongs to them. (In-class Workshop, March 21, 2017)

In this case, the in-class workshop aided students in understanding the content that would otherwise be complex and far removed from students.

Furthermore, other students alluded to the stereotype of a typical Hollywood ending, presenting a white majority and minorities in specific roles. However, the use of smallerscale movies, illustrating diverse perspectives, highlighted different aspects of American culture. After watching the Hollywood-Bollywood production, My Name is Khan (Johar, 
2010), one student reflected on the experience of viewing an alternative take on the struggles of minority groups in the U.S.:

I expected it to be the typical American movie with a dream ending, where there are whites, blacks, and latinos and it develops around a series of mostly moving circumstances. But when I saw it, I thought it was a sincere and raw movie about what really happens in societies around the world that influences how we coexist and what we ignore voluntarily or involuntarily. (In-class Workshop, February 6, 2017)

In this context, the students were also able to relate what they saw to different societies worldwide. They could perceive certain social issues from specific contexts as global issues, and not just exclusive to one context.

Moreover, in going beyond mainstream representations, students noted the role of the director in depicting such perspectives. One student highlighted how the directors' points of view can sometimes create a particular narrative of the movie; they present certain aspects in particular ways to generate more attention-grabbing points of view. As a student mentioned, "sometimes the other parts of the movie get away from the topic, (...) the producers give a specific point of view, or imprint a specific view." (Focus Group, June 5, 2017). Still, with the tools of the workshops and class materials, most students could decode what they were presented with, and attempted to dissect the multiple perspectives of the varying characters.

\section{Guidance for further analyses and more information}

Although students had previously watched some of the movies, they had not seen them with a critical lens. For example, the movie $V$ for Vendetta (McTeigue, 2005) is commonly shown on cable channels; however, students had not seen it within the context of political critique and with certain historical background. Also, some characters in movies impacted students, which motivated them to search for more information. For instance, in the class of Language, Culture and Identity, one of the students was impressed by the speech given by the character of Dr. Ernst Janning, in the movie Judgment at Nuremberg (Kramer, 1961) and was eager to know more about this character and the context of WWII (Field notes, February 22, 2017). Additionally, in watching The Danish Girl (Bevan, 2015), one student began to think more critically about sexuality and gender. She asserted,

The Danish girl did not change my perspective but it made me (...) confront my perspective because it represented a different case. It could teach something that you 
didn't know. It generates healthy curiosity (...) It made me research the topic (Field notes, May 16, 2017).

Similarly, students from Intercultural Communication recalled becoming more perceptive and analytical when watching any type of movie whether commercial or independent; the exercises during the workshop ingrained a more critical approach in viewing movies. One student said, "When I see movies I remember class, power, race, so I become critical watching movies" (Focus group, June 5, 2017). In this way, movies also help in pushing students to question their preconceived ideas about various social issues.

When students are guided into noticing the political, historical, and social aspects of film, they want to deepen their knowledge. Other participants became aware of the role they have as consumers of movies. One of the students, for example, stated that one of the disadvantages of using movies as a pedagogical tool would be, "Just limit yourself to the content seen in the movie. Hollywood creates its own stories, it includes things that are not true. It depends on the person, doing their own research" (Focus group, June 6, 2017).

Schwarz (2001) describes how media messages are pervasive in American contemporary world, which is true for all regions and cultures; people are exposed to different media which are saturated with many messages, and on occasions, transmitted through a multiplicity of formats. This saturation of media messages sometimes stuns people, especially young people, who only pay attention to the first layers of meaning present in media. Therefore, it is necessary to acknowledge that the concept of literacy has expanded, making it necessary to reevaluate the tools teachers use to foster these literacies.

The students participating in this study emphasize that without proper guidance, they would have continued with general analyses of basic ideas in the film or may have been distracted by the superficial aspects of the plots. One of the participants said, "Maybe people won't be able to relate easily the story that is easy to see (...) if it is a romantic movie, people will pay attention to the romantic story, but not to the background." (Focus group, June 6, 2017). Another participant who watched District 9 (Blomkamp, 2009), in the series of dystopian movies stated, "Maybe others may perceive this film since (sic) one gaze, more of entertainment, because they have not received all these topics that I've learned in Language, Culture and Identity" (Focus group, June 6, 2017). 
These examples show that media literacy skills are not naturally acquired, but need to be taught. Robinson as cited by Schwarz (2001, p. 112), affirms, "media literacy education teaches ways to analyze the carefully constructed codes and conventions of media and how it affects one's understanding of his or her world." Thus, students need assistance in becoming familiar with the language of media to unmask their hidden messages which means questioning, challenging, and being conscious of social environments, as well as common representations of certain characters (Thoman, 1999).

\section{CONCLUSIONS}

The varying implementations using film as a critical resource illustrate the multiple ways in which such a tool is integral to intercultural courses. We identified three particular ways in which film can be incorporated as a pedagogical strategy, highlighting a multiplicity of intercultural themes: film is an agent in promoting global citizenship; it is important that film provides a more rounded perspective of marginalized groups which can be better related to the experiences of certain students from the Global South; these diverse stories assist in decolonizing mainstream and essentialized forms of learning about Anglophone culture(s). It is evident that further research is required to help students create counter-narratives which can be catalyzed by the films they watch.

Film can be an aid in fostering global citizenship and allowing students to see themselves within varying socio-cultural contexts. As Kellner and Share (2005) asserts, film provides critical literacy in which students are able to witness the varying perspective of language, power, social practices and social groups. This foments broader analytical skills to see beyond images, and critically engage in understanding different viewpoints. In many ways, film allows students to become critical global citizens, who are conscious of the impact of certain global-order hierarchies (Andreotti, 2006). Students were encouraged to see past mainstream representations of certain social groups, and apply critical thinking skills to engage in deeper analyses of the different social settings and groups they saw on screen. At the same time, they connected these contexts to their own everyday lives, allowing them to see themselves as part of, not separate from, global dynamics.

Additionally, as evidenced by the data, the social backgrounds of the various characters in the movies were indispensable in allowing students to relate their experiences to 
those of the differing characters. In reflecting on this, we argue that it is essential that movies used in classrooms depict the experiences of marginalized groups, especially when working with students from precarious backgrounds and ESL students from countries in the Global South. Movies are often perceived as a form of cultural and linguistic imperialism, imposing a standard way of viewing a skewed portrayal of American culture and ways of speaking (Hooks, 1997; Phillipson, 2008). Fandiño (2014) notes that Colombian language teachers tend to essentialize Western culture when teaching about intercultural aspects in EFL classrooms. Therefore, it is important to decolonize ESL teaching practices, especially, when incorporating intercultural topics.

Colombia has been heavily influenced by American interventionist policies and corporations, which tends to impact ways of thinking and public critiques (Gorski, 2008). In recent years, the Colombian government has implemented a Bilingual program, which, using the Common European Framework for Languages (2001), aims to have an increase of 50\% in the number of high school students at a B1 level of English by 2025 (Colombian National Ministry of Education, 2014). A large part of this program aims to foster intercultural awareness through teaching English. Nonetheless, it is important to consider that mere cultural awareness masks the multifaceted local contexts within Colombia and can disenfranchise the experiences and stories of more marginalized populations (Gorski, 2008; de Mejía, 2011). As shown through the data, movies that depict the stories of more marginalized groups, could be a fundamental tool in decolonizing perceptions of the intercultural. They can help in debunking hegemonic constructions of 'culture' and stimulate critical consciousness amongst students. In doing so, both educators and students must acknowledge that ideas of 'culture' may be inherently essentialized (Dervin, 2010). Still, in representing and recognizing the multiple factors and identities that influence culture such as race, ethnicity or gender, a more critical analysis can emerge. However, this can only be done if the educator serves as a 'critical cultural agent' and mediator for their students (Arikan, 2002).

Furthermore, it is important to include ways for students to create their own stories in relation to the themes highlighted in the movies. Media literacy is cultural, critical and creative (Burn \& Durran, 2007). Recently there has been a move from critique to production, especially due to the advent of technological authoring and editing tools which facilitate students' counteracting hegemonic narratives by creating their own stories; this aspect of 
creation and its integration with criticality and local contexts deserves further research (Burn \& Durran, 2007). Also, Solórzano and Yosso (2002) describe counter-storytelling as, "a method of telling the stories of those people whose experiences are not often told" (p. 26); this means offering subaltern communities - people of colour, women, sexually diverse and poor - opportunities for their voices to be heard. As the participants in this study were both aware of and concerned about the ways Hollywood constructs hegemonic representations and meanings, this awareness could trigger the production of counter-narratives that question racism, classism, sexism and heterosexism. Further research could look at how counternarratives can be constructed using film as a basis.

Although the results illustrated the positive aspects of using film, it is important to recognize that as both researchers were teachers of the courses, students could have maintained a certain bias in responding to the questions and participating in the workshops. In some cases, students may not have been honest when responding or may have skewed their answers to fit our perceptions. Still, it was evident that in looking at students' processes throughout the courses, the films used assisted them in enhancing their understandings of complex topics such as race, gender, and sexuality. Students' understandings of the experiences of marginalized groups and identities were strengthened by the visual representations presented in movies such as Crash (Haggis, 2004), and the deep analytical discussions that occurred after each movie.

At the same time, it is difficult to decipher whether or not students will maintain these critical analyses aside from the two courses; from our observations we saw that many times this was related to students' interests and personal beliefs. For these reasons, students were encouraged to not just be critical, but view the dialogical relationships from multiple perspectives within the films. Such an analysis may allow students to develop an informed position about the issues depicted in the movies and related to the themes discussed in class.

Thus, it must be noted that film is an effective tool for promoting intercultural awareness solely if both students and teachers are provided with the right training to read and write different media texts (Burn \& Durran, 2007). In doing so, film may be integral in fostering critical global citizenship and decolonizing and questioning the way in which interculturality has been constructed. 


\section{REFERENCES}

Andreotti, V. O. (2014). Soft versus critical global citizenship education. In Development education in policy and practice (pp. 21-31). UK: Palgrave Macmillan.

Arikan, A. (2002). Chapter nine: critical media literacy and ESL/EFL classrooms. Counterpoints, 176, 113-124.

Bevan, T., Fellner, E., Harrison, A., Hooper, T. \& Mutrux, G. (Producers) \& Hooper, T. (Director). (2015). The Danish Girl. [Film]. United Kingdom, United States: Focus Features \& Universal Pictures.

Briam, C. (2010). Outsourced: Using a comedy film to teach intercultural communication. Business Communication Quarterly, 73(4), 383-398.

Burn, A. \& Durran, J. (2007). Media literacy in schools. Practice, production and progression. London: Paul Chapman Publishing.

Byram, M. (1997). Teaching and assessing intercultural communicative competence. Multilingual Matters.

Byram, M. (2008). From foreign language education to education for intercultural citizenship. Clevedon: Multilingual Matters.

Byram, M. (2012). Language awareness and (critical) cultural awareness - relationships, comparisons and contrasts. Language Awareness, 21(1-2), 5 - 13.

Cheadle, D., Haggis, P., Harris, M., Moresco, B., Schulman, C. \& Yari, B. (Producers) \& Haggis, P. (Director). (2004). Crash. United States \& Germany: Lionsgate Films.

Council of Europe (2001). Common European Framework of Reference for Languages: Learning, Teaching Assessment. Cambridge: Cambridge University Press.

Creswell, J. W. (2007). Qualitative Inquiry and Research Design. Choosing among five approaches. Thousand Oaks: SAGE Publications.

Dervin, F. (2010). Assessing intercultural competence in Language Learning and Teaching: a critical review of current efforts. In F. Dervin \& E. Suomela-Salmi (Eds.). New Approaches to Assessment in Higher Education. (157-173). Bern: Peter Lang.

Dervin, F. (2016). Interculturality in Education. A theoretical and methodological toolbox. London: Palgrave Macmillan.

Déry, L. \& McCraw, K. (Producers) \& Villeneuve, D. (Director). 2010. Incendies [Motion Picture]. Canada: E1 Entertainment \& Sony Pictures Classics.

Dietz, G. \& Mateos, L. (2012). The need for comparison in intercultural education. Intercultural Education, 23:5, 411-424. 
Du Gay, P., Hall, S., Janes, L., McKay, H. \& Negus, K. (1997). Doing cultural studies. The story of the Sony Walkman. London: SAGE Publication \& The Open University.

Fandiño, Y. J. (2014). Teaching culture in Colombia Bilingüe: From theory to practice. Colombian Applied Linguistics Journal, 16(1). 81-92.

Gall, M., Gall, J. \& Borg, W. (2003). Educational Research. An Introduction. Boston: Pearson Education.

García, A., Seglem, R. \& Share, J. (2013). Transforming Teaching and Learning Through Critical Media Literacy Pedagogy. In LEARNing Landscapes, (6), 2, Spring.

Giroux, H. A. (2001). Breaking into the movies: Pedagogy and the politics of film. JAC, 583598.

Gorski, P. (2008). Good intentions are not enough: decolonizing intercultural education. Intercultural Education, 19:6, 515-525.

Grosfoguel, R. (2011). Decolonizing Post-Colonial Studies and Paradigms of PoliticalEconomy: Transmodernity in Decolonial Thinking, and Global Coloniality. Transmodernity: Journal of Peripheral Cultural Production of the Luso-Hispanic World, 1(1).

Hall, S. (1980). Encoding/decoding. In S. Hall, D. Hobson, A. Lowe, \& P. Willis (Eds.), Culture, media, language (pp. 128-138). London, UK: Hutchinson.

Hall, S. (1997). Representation \& the media. Northampton, MA: Media Education Foundation.

Holliday, A. (2011). Intercultural Communication and Ideology. London: Sage Publications.

Hancock, D. R. \& Algozzine, B. (2006). Doing case study research. A practical guide for beginning researchers. New York: Teachers College Press.

Higbee, W. and Lim Hwee S. (2010). Concepts of transnational cinema: towards a critical transnationalism in film studies. Transnational Cinemas, 1(1): 7-21.

Himmelmann, G. (2003). Zukunft, Fachidentität und Standards der politischen Bildung. Unpublished manuscript. Braunschweig: TU Braunschweig, Institut für Sozialwissenschaften.

Hooks, B. (1997). Cultural criticism and transformation. Sut Jhally (Producer) Interview Transcript. Northampton: Media Education Foundation.

Houghton, S. (2013). Introduction. In S. Houghton, Y. Furumura, M. Lebedko \& Li, S. (Eds.). Critical Cultural Awareness: Managing Stereotypes through Intercultural (Language) Education. Newcastle-upon-Tyne, UK: Cambridge Scholars Publishing.

Jackson, P. \& Cunningham, C. (Producers) \& Blomkamp, N. (Director). (2009). District 9. [Motion Picture]. South Africa, New Zealand: TriStar Pictures.

Johar, H. and G. Khan (Producers), \& Johar, K. (Director). 2010. My Name is Khan [Motion Picture]. India: Fox Star Studios \& Twentieth Century Fox. 
Kellner, D., \& Share, J. (2005). Toward critical media literacy: Core concepts, debates, organizations, and policy. Discourse: studies in the cultural politics of education, 26(3), 369-386.

Kramer, S. (Producer) \& Kramer, S. (Director). (1961). Judgment at Nuremberg. [Motion Picture]. United States: United Artists

Kramsch, C. (1995). The cultural component of language teaching. Language, Culture \& Curriculum, 8(2), 83 - 92

Kubota, R. \& Lin, A. (2006). Race and TESOL: Introduction to concepts and theories. TESOL Quarterly, 40(3), 471 - 493

Media Smarts. Canada's Centre for Digital and Media Literacy. (2005). Media literacy fundamentals. Retrieved from http://mediasmarts.ca/digital-media-literacy/generalinformation/digital-media-literacy-fundamentals/media-literacy-fundamentals

Mejía, A.M. de (2011). Bilingual Education in Colombia: Towards a Recognition of Languages, Cultures and Identities. Apples- Journal of Applied Language Studies, 5(3), 7-17.

Ministerio de Educación Nacional. (2014). Colombia Very Well. Programa Nacional de Inglés 2015 -2025. [PowerPoint Presentation]. Bogotá: Ministerio de Educación Nacional.

Ministerio de Educación Nacional. República de Colombia (2003). Estándares Básicos de Competencias Ciudadanas. Formar para la ciudadanía isí es posible! Lo que necesitamos saber y saber hacer. [Basic Standards of Citizenship Competences. Educating for citizenship is possible. What we need to know and know how to do]. Bogotá, Colombia.

Moncada, S. (2016). Othering: Towards a Critical Cultural Awareness in the Language Classroom. How Journal (23)1, 129 - 146

Müller- Hartmann, Andreas \& Schocker-von Ditfurth; Marita (2007). Introduction to English Language Teaching. Stuttgart: Klett.

Neiman, G. \& Quaranta, G. (2006). Los estudios de caso en la investigación sociológica. In I. Vasilachis (Coord.). Estrategias de Investigación Cualitativa. Barcelona: Gedisa.

Nugent, K. \& Catalano, T. (2015). Critical cultural awareness in the foreign language classroom. NECTFL Review, 75, 15-30. Retrieved from http://digitalcommons.unl.edu/cgi/viewcontent.cgi?article=1193\&context=teachlearnf $\underline{\text { acpub }}$

OXFAM. (1997). A curriculum for global citizenship. Oxford, UK: OXFAM

Parekh, B (2003). Cosmopolitanism and Global Citizenship. Review of International Studies (29)1, 3-17

Pegrum, M. (2008). Film, culture and identity: Critical intercultural literacies for the language classroom. Language and Intercultural Communication, 8(2), 136-154. 
Phillipson, R. (2008). The Linguistic Imperialism of Neoliberal Empire. Critical Inquiry in Language Studies, 5(1),1-43

Robinson, J. (1996). Introduction to media literacy in education and media literacy education bibliography. Indianapolis: Media Action Council of Indiana.

Rogow, F. (2007). Media Literacy Questions for Analyzing POV Films. Adapted from NAMLE's Core Principles of Media Literacy Education in the United States. Retrieved from https://pov-tc.pbs.org/pov/docs/POV_medialiteracy.pdf

Schwandt, T. (2007). The Sage Dictionary of Qualitative Inquiry. Thousand Oaks, CA: Sage Publications.

Schwarz, G. (2001). Literacy Expanded: The Role of Media Literacy in Teacher Education. Teacher Education Quarterly, 28(2), 111-119

Silver, J., Hill, G., Wachowski, A., \& Wachowski, L. (Producers) \& McTeigue, J. (Director). (2005). V for Vendetta. [Motion Picture]. United States, United Kingdom, Germany: Warner Bros.

Solórzano, D. G. \& Yosso, T. J. (2002). Critical race methodology: Counter-Storytelling as an analytical framework for education. Qualitative Inquiry, 8(1), 23-44.

Spivak, G.C. (1988). Can the Subaltern speak?. In C. Nelson \& L. Grossberg (Eds.), Marxism and the Interpretation of Culture (pp. 271-313). Chicago: University of Illinois Press.

Stake, R. (1995). The Art of Case Study Research. Thousand Oaks, CA: Sage Publications.

Thoman, E. (1999). Skills and strategies for media education. Educational Leadership, 56(5), $50-54$.

Truong, L. B., \& Tran, L. T. (2014). Students' intercultural development through language learning in Vietnamese tertiary education: A case study on the use of film as an innovative approach. Language and Intercultural Communication, 14(2), 207-225.

UNESCO, (2015). Global citizenship education. Topics and learning objectives. Paris: United Nations Educational, Scientific and Cultural Organization.

UNESCO, (2014). Global citizenship education. Preparing learners for the challenges of the 21st century. Paris: United Nations Educational, Scientific and Cultural Organization.

Vodopivek, N. (2012). Challenging global citizenship through interculturality: Crossing borders and practicing solidarity. Critical Literacy: Theories and Practices 6(1), 58 63

Yin, R. (2003). Case Study Research. Design and Methods. Thousand Oaks: SAGE Publications. 
Appendix 1

Name:

Date:

Course:

\section{Workshop on Film and Cultural Contexts}

\section{MOVIE TITLE:}

\section{Understanding the film}

1) What is the setting of the movie? Where does it take place and in what time period?

2) Who are the main characters in the movie? How are they interconnected?

3) What is the main conflict in the movie?

4) Was the conflict solved? How so?

II. Film Analysis

5) What are themes in the movie that can be related to the class?

6) Did the movie give you more information about those themes? How so?

7) What are situations or ideas illustrated in the movie that can be applied to Colombian society?

III. Interpretation and Assessment

8) What is your reaction to the film? What have you learned about yourself from this reaction?

9) How might others perceive this film differently from your perspective? Why might these varying interpretations occur?

10) How does the director construct the story(ies) within the film? Is it believable? How so?

11) Which historical events can be related to the movie? 
Appendix 2

\section{Focus Group Questions}

\section{Film and Interculturality}

a. Did the movies contribute to your understanding of the topics developed in class? If so, how?

b. What could be the advantages and disadvantages of using film as a means to complement theoretical explanations?

c. After watching the movie, you had to develop a workshop. How effective was the workshop in guiding you towards a deeper understanding of the film(s)?

d. How would you suggest following-up the work done with the movies as a pedagogical tool?

e. Which pedagogical implications do you see for this pedagogical use of movies in your future as an educator?

\section{Aspects relating to citizenship}

a. Did the movies you selected create a conflict between your own perspectives and values and those present in the movie? If so, which ones?

b. How did you approach those conflicts? Did you solve them or not? Why?

c. Do you think that you were able to develop empathy towards certain individuals or social groups by means of the selection of movies you saw?

d. Do you think the selection of movies could contribute to transform yourself as an individual, for example, in relation to prejudices you may have about certain individuals or groups of people?

e. Do you think the selection of movies seen for this class could contribute to the construction of citizenship? Yes / No Why? 